Jurnal Kesehatan

Volume 11, Nomor 2, Tahun 2020

ISSN 2086-7751 (Print), ISSN 2548-5695 (Online)

http://ejurnal.poltekkes-tjk.ac.id/index.php/JK

\title{
Kelelahan Kerja pada Pekerja di PT. Indonesia Power Unit Pembangkitan dan Jasa Pembangkitan (UPJP) Priok
}

\section{Work Fatigue of Workers at PT. Indonesia Power Unit Pembangkitan dan Jasa Pembangkitan (UPJP) Priok}

\author{
Eka Dhiffa Safira $^{1}$, Rafiah Maharani Pulungan ${ }^{2}$, Cahya Arbitera $^{3}$ \\ Fakultas Ilmu Kesehatan, Universitas Pembangunan Nasional Veteran Jakarta, Indonesia
}

\section{ARTICLE INFO}

\section{Article history}

Received date

10 August 2020

Revised date

01 Sept 2020

15 Sept 2020

Accepted date

16 Sept 2020

Keywords:

Main workshop;

Mechanics;

Work fatigue.

\section{Kata kunci:}

Bengkel utama;

Mekanik;

Kelelahan kerja.

\author{
ABSTRACT/ ABSTRAK
}

\begin{abstract}
Work fatigue is an important problem that needs to be resolved because can cause work accidents and can have an impact on workers' health. Based on the result of interviews in early 2020, there was one worker who was unconscious due to work fatigue where a similar case had never happened before in the last 5 years. Workers complain of feeling dizzy, tired all over, fever, frequent drowsiness, trembling, feeling heavy in the head, and feeling thirsty while working. The purpose of this study was to identify the factors associated with work fatigue at PT. Indonesia Power Unit Pembangkitan dan Jasa Pembangkitan (UPJP) Priok. This research was a quantitative-analytic study with a crosssectional design. The population of this research was 81 workers consisting of 11 workers in the main workshop and 70 workers in the mechanical part. The sample of this research was 40 workers in the main workshop and mechanics section which were obtained by a purposive sampling technique. The results show that $57,5 \%$ of workers have experienced a high category of work fatigue. Statistical analysis shows that nutritional status ( $\mathrm{p}$ value $=0,034)$ and sleep quality ( $\mathrm{p}$-value $=0,028)$ were related to work fatigue, while the length of work ( $p$-value $=0,299)$, workload $(p$-value $=0,100)$ and age $(p$-value $=1,000)$ were not related to work fatigue. Therefore, workers were suggested to consume foods with high carbohydrate content, adequate-protein, calorie intake, and vitamins, as well as regulating duration and hours of sleep following the Ministry of Health's standards, namely 7-8 hours per day for adults (ages 18-40 year).
\end{abstract}

\begin{abstract}
Kelelahan kerja merupakan masalah penting yang perlu ditanggulangi karena dapat menyebabkan kecelakaan kerja dan dapat berdampak pada kesehatan pekerja. Berdasarkan hasil wawancara pada awal tahun 2020, terdapat satu pekerja yang tidak sadarkan diri akibat kelelahan kerja dimana kasus serupa belum pernah terjadi sebelumnya dalam kurun waktu 5 tahun terakhir. Pekerja mengeluh merasa pening, lelah seluruh tubuh, demam, sering mengantuk, gemetar, merasa berat di kepala, dan merasa haus saat bekerja. Tujuan penelitian ini adalah mengetahui faktor-faktor yang berhubungan dengan kelelahan kerja di PT. Indonesia Power Unit Pembangkitan dan Jasa Pembangkitan (UPJP) Priok. Penelitian bersifat analitik kuantitatif dengan desain penelitian cross-sectional. Populasi penelitian berjumlah 81 orang, yang terdiri dari 11 orang pekerja bagian bengkel utama dan 70 orang pekerja bagian mekanik. Sampel penelitian berjumlah 40 pekerja yang diperoleh dengan teknik purposive sampling. Hasil penelitian menunjukan sebanyak $57,5 \%$ pekerja mengalami kelelahan kerja kategori tinggi. Hasil analisis statistik menunjukan status gizi $(p$-value $=0,034)$ dan kualitas tidur $(p$-value $=0,028)$ memiliki hubungan dengan kelelahan kerja, sedangkan masa kerja ( $p$ value $=0,299)$, beban kerja ( $p$-value $=0,100)$, dan usia $(p$-value $=1,000)$ tidak memiliki hubungan dengan kelelahan kerja. Oleh karena itu, peneliti menyarankan pekerja untuk mengonsumsi makanan yang mengandung karbohidrat tinggi, protein, asupan kalori, dan vitamin yang cukup, serta mengatur jam dan durasi tidur sesuai dengan standar kemenkes yaitu 7-8 jam setiap hari untuk orang dewasa (usia 18-40 tahun).
\end{abstract}

Corresponding Author:

Eka Dhiffa Safira

Fakultas Ilmu Kesehatan, Universitas Pembangunan Nasional Veteran Jakarta, Indonesia

Email: dhiffaekas@gmail.com 


\section{PENDAHULUAN}

Kelelahan kerja merupakan situasi fisik tubuh, kegiatan, dan motivasi yang melemah untuk mengerjakan pekerjaan (Maharja, 2015). Kelelahan adalah keadaan dimana kekuatan tubuh untuk melakukan kegiatan yang sama berkurang dan efisiensi performa kerja menurun (Ningsih and Nilamsari, 2018). Kelelahan kerja menjadi salah satu persoalan krusial yang perlu ditanggulangi karena kelelahan dapat menyebabkan kecakapan kerja menghilang, kondisi kesehatan menurun sehingga dapat memicu kecelakaan kerja, serta produktivitas dan prestasi kerja menurun (Verawati, 2016). Kelelahan kerja dalam jangka waktu yang lama juga akan berpengaruh pada kesehatan pekerja. Beberapa risiko kesehatan yang dapat timbul akibat kelelahan kerja yang berkepanjangan meliputi anxiety, penyakit jantung, diabetes, tekanan darah tinggi, gangguan gastrointestinal, penurunan kesuburan dan depresi (Mustofani and Dwiyanti, 2019).

Faktor penyebab kelelahan kerja ada dua aspek, yaitu aspek eksternal (lingkungan kerja dan pekerjaan) dan aspek internal (karakteristik individu). Unsur pekerjaan meliputi beban kerja, shift kerja, dan periode kerja. Unsur individu meliputi jenis kelamin, keadaan gizi, kualitas tidur, usia, dan kebiasaan merokok (Suma'mur, 2014). Unsur lingkungan kerja antara lain lingkungan kerja fisik dan non-fisik. Bersumber pada Permenaker RI Nomor 5 Tahun 2018 mengenai K3 Lingkungan Kerja, faktor fisik lingkungan kerja terdiri dari kebisingan, iklim kerja, gelombang radio atau mikro, getaran, pencahayaan, sinar ultraviolet (UV), tekanan udara, dan medan magnet statis. Lingkungan kerja nonfisik meliputi ikatan kerja antara atasan dengan bawahan, serta hubungan kekerabatan antar sesama pekerja. Faktor tersebut dapat menyebabkan ketidaknyamanan dalam bekerja dan apabila berlangsung lama, kelelahan dapat terjadi (Juliana, Camelia, dan Rahmiwati, 2018).

Pada tahun 2013, Kementerian Tenaga Kerja (Kemenaker) Jepang melaksanakan pengkajian terhadap 12.000 perusahaan dengan sampel sebesar 16.000 pekerja, hasil kajian menunjukkan $7 \%$ pekerja mengalami stress berat, $28 \%$ mengalami kelelahan psikis, dan $65 \%$ tenaga kerja mengalami kelelahan tubuh (ILO, 2013). International Labour Organitation atau ILO (2013) menuturkan dua juta pekerja menjadi objek korban tiap tahunnya karena mengalami kecelakaan kerja sebagai efek dari kelelahan (ILO, 2013). Penelitian yang dilakukan National Safety Council (NSC) terhadap 2.010 tenaga kerja di Amerika Serikat tahun 2017 menujukkan bahwa kurang lebih 13\% kecelakaan di tempat kerja terjadi karena faktor kelelahan. Berdasar pada penelitian tersebut diketahui $97 \%$ pekerja setidaknya memiliki satu faktor dan lebih dari $80 \%$ memiliki dua atau lebih faktor risiko kelelahan kerja. 40\% tenaga kerja di Amerika Serikat memberitahu bahwa mereka mengalami kelelahan kerja yang memicu terjadinya peningkatan angka absensi, penurunan produktivitas, serta peningkatan jumlah kecelakaan kerja (NSC, 2017).

Berdasarkan data Dirjen Pembinaan Pengawasan Ketenagakerjaan (Binwasnaker), pada tahun 2012 kasus kecelakaan kerja di Indonesia sebesar 847 kasus dan 36\% di antaranya terjadi karena tingkat kelelahan kerja yang tinggi (Binwasnaker, 2012). Data dari International Labour Organitation (ILO) menunjukkan sekitar 32\% pekerja dunia mengalami kelelahan akibat pekerjaan yang mereka lakukan. Tingkat keluhan kelelahan berat pada pekerja di seluruh dunia berkisar antara 18,3-27\% dan tingkat prevalensi kelelahan di industri sebesar 45\% (ILO, 2016).

PT. Indonesia Power yang berdiri sejak 3 Oktober 1995 merupakan anak perusahaan PT. PLN yang dulunya terkenal dengan nama PT PLN Pembangkit Jawa Bali (PT PJB I). Unit Pembangkitan dan Jasa Pembangkitan Priok (UPJP) Priok merupakan satu dari delapan unit utama PT. Indonesia Power. Berdasarkan studi pendahuluan, menurut kepala bagian bengkel utama dan mekanik PT. Indonesia Power UPJP Priok diketahui bahwa pada awal tahun 2020 ada satu pekerja yang mengalami pingsan atau tidak sadarkan diri akibat kelelahan kerja, dimana kasus serupa belum pernah terjadi sebelumnya dalam kurun waktu 5 tahun terakhir. Berdasarkan hasil wawancara beberapa pekerja pada bagian mekanik dan bengkel utama mengeluh merasa pening, lelah seluruh tubuh, demam, sering mengantuk, gemetar, merasa berat di kepala, dan merasa haus saat bekerja. Berdasarkan hal tersebut, perlu diadakan penelitian mengenai kelelahan kerja pada pekerja di PT. Indonesia Power Unit Pembangkitan dan Jasa Pembangkitan (UPJP) Priok.

Tujuan umum penelitian adalah mengetahui faktor-faktor yang berhubungan dengan kelelahan kerja di PT. Indonesia Power Unit Pembangkitan dan Jasa Pembangkitan (UPJP) Priok. Hasil penelitian diharapkan dapat digunakan sebagai dasar dalam pencegahan kelelahan bagi para pekerja, sebagai bahan masukan bagi perusahaan untuk menentukan langkah pencegahan dan pengendalian 
kecelakaan kerja yang disebabkan karna kelelahan kerja, serta memperluas pengetahuan dan wawasan mahasiswa tentang faktor yang berkaitan dengan kelelahan kerja.

\section{METODE}

Penelitian bersifat analitik kuantitatif dengan desain penelitian cross-sectional. Populasi penelitian adalah seluruh tenaga kerja yang bekerja pada bagian bengkel utama dan mekanik. Sampel penelitian yaitu setengah dari total tenaga kerja bagian mekanik dan bengkel utama di PT. Indonesia Power Unit Pembangkitan dan Jasa Pembangkitan (UPJP Priok). Teknik pengambilan sampel yang digunakan yaitu dengan metode purposive sampling, karena pengambilan sampel dilakukan berdasarkan pertimbangan yang dibuat oleh peneliti (Barlian, 2016). Variabel dependen penelitian ini yaitu kelelahan kerja, dan variabel independen yaitu karakteristik individu (status gizi, usia, dan kualitas tidur), serta pekerjaan (masa kerja dan beban kerja). Jenis data yang digunakan ada dua yaitu data primer dan data sekunder. Data primer berupa pengisian google form yang terdiri dari kuesioner Industrial Fatigue Research Committe (IFRC), kuesioner Pittsburgh Sleep Quality Index (PSQI), serta kuesioner NASA-TLX. Data sekunder berupa deskripsi umum perusahaan, serta data berat badan dan tinggi badan pekerja. Sumber data didapatkan dari wawancara, dan kuesioner.

Penelitian ini telah mendapatkan persetujuan etik (Ethical Approval) Nomor. 2539/VI/2020/KEPK dari Komisi Etik Penelitian Kesehatan Universitas Pembangunan Nasional Veteran Jakarta.

HASIL

Tabel 1. Distribusi Frekuensi Kelelahan Kerja

\begin{tabular}{lrr}
\multicolumn{1}{c}{$\begin{array}{c}\text { Variabel Kelelahan } \\
\text { Kerja }\end{array}$} & \multicolumn{1}{c}{ n } & \multicolumn{1}{c}{$\%$} \\
\hline Sangat tinggi & 0 & 0 \\
Tinggi & 23 & 57,5 \\
Sedang & 17 & 42,5 \\
Rendah & 0 & 0 \\
\hline
\end{tabular}

.

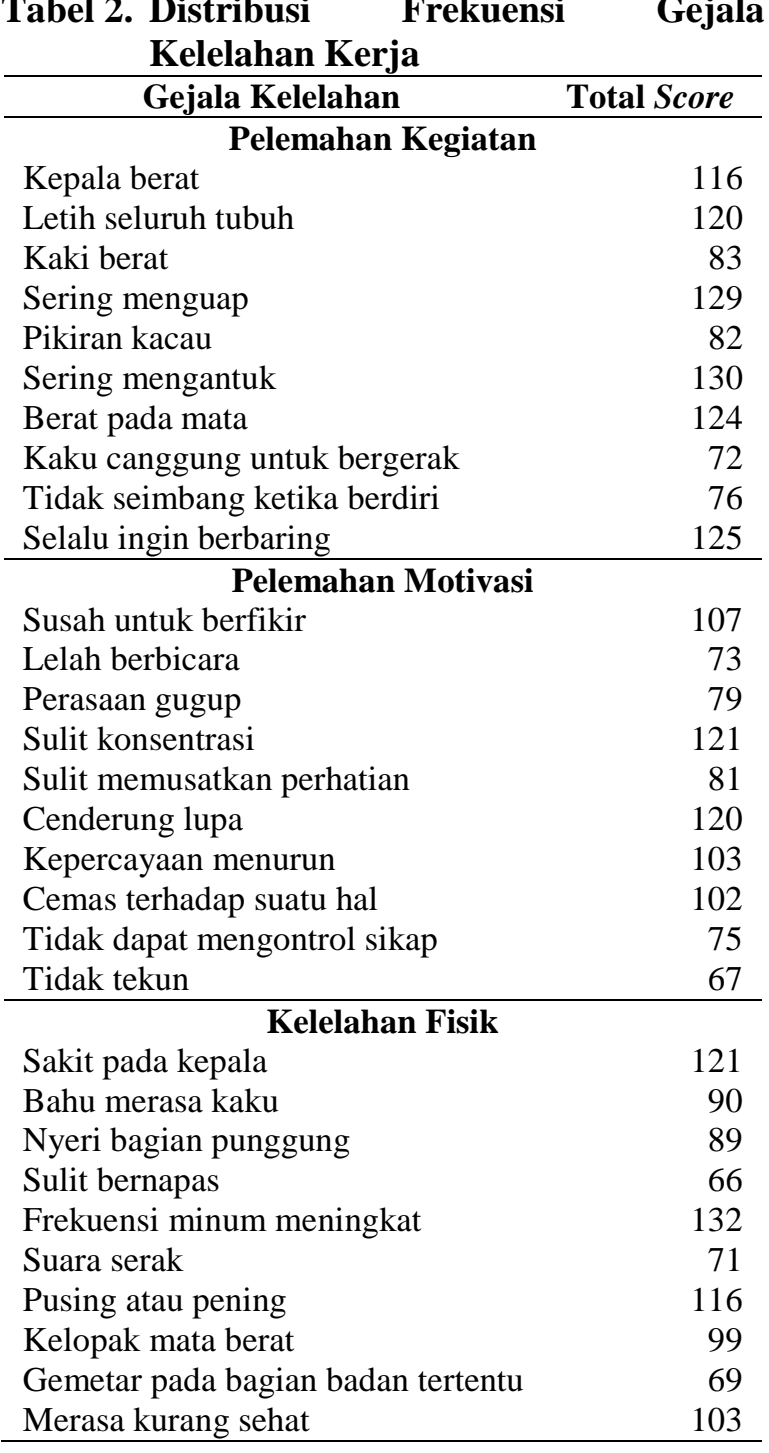

Tabel 3. Distribusi Frekuensi Faktor Pekerjaan (Masa Kerja dan Beban Kerja) dan Faktor Individu Pekerja (Usia, Status Gizi, dan Kualitas Tidur)

\begin{tabular}{|c|c|c|}
\hline Variabel & $\mathbf{n}$ & $\%$ \\
\hline \multicolumn{3}{|c|}{ Masa Kerja } \\
\hline$>4,5$ tahun & 14 & 35 \\
\hline$\leq 4,5$ tahun & 26 & 65 \\
\hline \multicolumn{3}{|c|}{ Beban Kerja } \\
\hline Sangat Tinggi & 26 & 65 \\
\hline Tinggi & 14 & 35 \\
\hline Agak tinggi & 0 & 0 \\
\hline Sedang & 0 & 0 \\
\hline Rendah & 0 & 0 \\
\hline \multicolumn{3}{|c|}{ Usia } \\
\hline$>26$ tahun & 18 & 45 \\
\hline$\leq 26$ tahun & 22 & 55 \\
\hline \multicolumn{3}{|c|}{ Status Gizi } \\
\hline Gemuk & 16 & 40 \\
\hline Kurus & 7 & 17,5 \\
\hline Normal & 17 & $42,5 \%$ \\
\hline \multicolumn{3}{|c|}{ Kualitas Tidur } \\
\hline Buruk & 21 & $52,5 \%$ \\
\hline Baik & 19 & $47,5 \%$ \\
\hline
\end{tabular}


Berdasarkan tabel 1 , dapat dilihat dari 40 pekerja diperoleh 23 pekerja dengan persentase sebesar $57,5 \%$ mengalami kelelahan kerja kategori tinggi. Pada tabel 2 terlihat bahwa gejala kelelahan kerja yang paling sering dialami pekerja yaitu frekuensi minum meningkat dengan total score 132, dan sulit bernapas merupakan gejala kelelahan kerja yang jarang dirasakan oleh pekerja dengan total score yakni 66.

Pada tabel 3 tampak 26 pekerja dengan persentase $65 \%$ telah bekerja selama $\leq 4,5$ tahun di PT. Indonesia Power UPJP Priok, dan sejumlah 26 pekerja dari totalnya 40 memiliki beban kerja yang sangat tinggi dengan persentase sebesar $65 \%$. Tabel di atas menjelaskan sebanyak 22 pekerja $(55 \%)$ berusia $\leq 26$ tahun. Rata-rata pekerja di UPJP Priok termasuk dalam kategori keadaan gizi normal yaitu sebanyak 17 pekerja $(42,5 \%)$ dan hanya 7 pekerja $(17,5 \%)$ yang keadaan gizinya kurus. Jumlah pekerja yang memiliki kualitas tidur yang buruk lebih banyak dari pekerja dengan kualitas tidur yang baik yakni ada 21 pekerja $(52,5 \%)$.

Tabel 4. Analisis Hubungan antara Faktor Pekerjaan (Masa Kerja dan Beban Kerja) dengan Kelelahan Kerja

\begin{tabular}{|c|c|c|c|c|c|c|c|c|}
\hline \multirow{3}{*}{ Variabel } & \multicolumn{6}{|c|}{ Kelelahan Kerja } & \multirow{3}{*}{ p-value } & \multirow{3}{*}{ OR $95 \%$ CI } \\
\hline & \multicolumn{2}{|c|}{ Tinggi } & \multicolumn{2}{|c|}{ Sedang } & \multicolumn{2}{|c|}{ Total } & & \\
\hline & n & $\%$ & $\mathbf{n}$ & $\%$ & $\mathbf{n}$ & $\%$ & & \\
\hline \multicolumn{9}{|l|}{ Masa Kerja } \\
\hline$>4,5$ tahun & 6 & 42,9 & 8 & 57,1 & 14 & 100 & \multirow{2}{*}{0,299} & 0,40 \\
\hline$\leq 4,5$ tahun & 17 & 65,4 & 9 & 34,6 & 26 & 100 & & $(0,10-1,50)$ \\
\hline \multicolumn{9}{|l|}{ Beban Kerja } \\
\hline Sangat tinggi & 12 & 46,2 & 14 & 53,8 & 26 & 100 & \multirow{2}{*}{0,100} & 0,23 \\
\hline Tinggi & 11 & 78,6 & 3 & 21,4 & 14 & 100 & & $(0,05-1,04)$ \\
\hline
\end{tabular}

Dari analisis tabel 4 dapat disimpulkan ada 17 pekerja $(65,4 \%)$ dari 26 pekerja yang sudah bekerja selama $\leq 4,5$ tahun di PT. Indonesia Power UPJP Priok merasakan kelelahan tinggi, dan 6 pekerja $(42,9 \%)$ yang telah bekerja selama $>4,5$ tahun juga mengalami kelelahan kerja tinggi. Hasil analisis tabel 4 sejumlah 11 pekerja $(78,6 \%)$ dengan beban kerja yang tinggi mengeluh mengalami kelelahan kerja kategori tinggi, dan sebanyak 12 pekerja $(46,2 \%)$ yang beban kerjanya sangat tinggi merasakan kelelahan tingkat tinggi juga. Nilai $\mathrm{p}$ untuk variabel beban kerja senilai 0,100 dan 0,299 untuk variabel masa kerja, sehingga Ho diterima yang artinya tidak ada asosiasi antara beban kerja dan masa kerja dengan kelelahan kerja.

Tabel 5. Analisis Hubungan antara Faktor Individu Pekerja (Usia, Status Gizi, dan Kualitas Tidur) dengan Kelelahan Kerja

\begin{tabular}{|c|c|c|c|c|c|c|c|c|}
\hline \multirow{3}{*}{ Variabel } & \multicolumn{6}{|c|}{ Kelelahan Kerja } & \multirow{3}{*}{ p-value } & \multirow{3}{*}{ OR 95\% CI } \\
\hline & \multicolumn{2}{|c|}{ Tinggi } & \multicolumn{2}{|c|}{ Sedang } & \multicolumn{2}{|c|}{ Total } & & \\
\hline & $\mathbf{n}$ & $\%$ & $\mathrm{n}$ & $\%$ & $\mathbf{n}$ & $\%$ & & \\
\hline \multicolumn{9}{|l|}{ Usia } \\
\hline$>26$ tahun & 10 & 55,6 & 8 & 44,4 & 18 & 100 & \multirow{2}{*}{1,000} & 0,86 \\
\hline$\leq 26$ tahun & 13 & 59,1 & 9 & 40,9 & 22 & 100 & & $(0,25-3,05)$ \\
\hline \multicolumn{9}{|l|}{$\overline{\text { Status Gizi }}$} \\
\hline Tidak Normal & 17 & 73,9 & 6 & 26,1 & 23 & 100 & \multirow{2}{*}{0,034} & 5,19 \\
\hline Normal & 6 & 35,3 & 11 & 64,7 & 17 & 100 & & $(1,33-20,28)$ \\
\hline \multicolumn{9}{|l|}{ Kualitas Tidur } \\
\hline Buruk & 16 & 76,2 & 5 & 23,8 & 21 & 100 & \multirow{2}{*}{0,028} & 5,49 \\
\hline Baik & 7 & 36,8 & 12 & 63,2 & 19 & 100 & & $(1,39-21,59)$ \\
\hline
\end{tabular}

Tabel 5 memaparkan dari total 22 pekerja yang berusia $\leq 26$ tahun ditemukan 13 pekerja $(59,1 \%)$ yang mengalami kelelahan tinggi, dan dari 18 pekerja yang berusia $>26$ tahun ada 10 pekerja $(55,6 \%)$ yang juga mengalami kelelahan kerja tinggi. Berdasarkan tabel 5 , didapatkan dari semua pekerja dengan jumlah 23 orang yang berstatus gizi tidak normal ada 17 pekerja $(73,9 \%)$ yang menderita kelelahan tinggi, dan sebanyak 6 pekerja $(35,3 \%)$ yang berstatus gizi normal juga menderita kelelahan kerja kategori tinggi. Dari 21 pekerja yang memiliki kualitas tidur yang buruk terlihat 16 pekerja $(76,2 \%)$ mengalami kelelahan kategori tinggi, dan dari total 19 pekerja yang kualitas tidurnya baik juga ada 7 pekerja $(36,8 \%)$ yang mengalami kelelahan tingkat tinggi. 
Hasil uji statistik didapatkan nilai $p$ value $=1,000$ untuk vaiabel usia, artinya tidak ada korelasi antara usia dengan kelelahan kerja. Nilai $p$-value untuk variabel status gizi sebesar 0,034 dan untuk variabel kualitas tidur sebesar 0,028 yang artinya ada asosiasi antara status gizi dan kualitas tidur dengan kelelahan kerja.

\section{PEMBAHASAN}

\section{Hubungan Masa Kerja dengan Kelelahan Kerja}

Hasil analisis chi-square diperoleh nilai $p$ value sebesar 0,299 yang artinya masa kerja tidak berhubungan dengan kelelahan kerja. Hasil tersebut sejalan dengan penelitian yang dilakukan oleh Wahyuni, dan Indriyani (2019) dengan nilai $p$-value sebesar 1,000 yang artinya tidak ada hubungan antara masa kerja dengan kelelahan kerja. Hasil tersebut bertolak belakang dengan penelitian Asriyani, Karimuna, dan Jufri (2017) dimana 19 pekerja $(63,3 \%)$ dengan masa kerja $>1$ tahun mengalami kelelahan kerja berat dan memproleh nilai $p$-value sebesar 0,01 yang artinya terdapat hubungan antara masa kerja dengan kelelahan kerja.

Hasil penelitian tidak sesuai dengan pendapat yang mengutarakan semakin lama masa kerja seseorang maka semakin tinggi pula tingkat kelelahannya (Asriyani, Karimuna and Jufri, 2017). Hal tersebut sejalan dengan teori Manuba (1992) dalam Wahyuni dan Indriyani (2019) yang berpendapat semakin lama seseorang bekerja, semakin tinggi keterampilan dalam melakukan pekerjaannya sehingga terbiasa dengan kelelahan yang dirasakan (Wahyuni and Indriyani, 2019). Kelelahan kerja kategori tinggi yang dirasakan oleh pekerja yang telah bekerja $\leq$ 4,5 tahun dapat dipengaruhi oleh unsur lain seperti beban kerja, karena berat ringannya beban kerja yang dipikul pekerja dapat menentukan berapa lama pekerja tersebut dapat melakukan pekerjaannya sesuai dengan kapasitas atau kemampuannya tersebut (Tarwaka, 2010).

\section{Hubungan Beban Kerja dengan Kelelahan Kerja}

Analisis chi square memperoleh $p$ value $=0,100$, artinya beban kerja tidak memiliki hubungan dengan kelelahan kerja. Analisis tersebut sejalan dengan penelitian Puspitasari, Wiediartini, dan Rosydah (2018) dengan $p$-value 0,876 artinya tidak ada hubungan antara beban kerja dengan kelelahan kerja pada pekerja bagian cetak pabrik pengecoran.

Pada penelitian ini walaupun beban kerja tidak berhubungan dengan kelelahan kerja akan tetapi sebagian besar pekerja memiliki beban kerja yang berat sehingga tidak menutup kemungkinan pekerja mengalami risiko penyakit tertentu (Asriyani, Karimuna and Jufri, 2017). Selain itu masih banyak faktor lain yang dapat menentukan besarnya beban kerja yang diterima oleh pekerja seperti lingkungan fisik, dan psikologis yang akan berpengaruh terhadap kinerja individu, dimana bila beban kerja yang dipikul terlalu berat dapat memicu terjadinya kelelahan baik mental maupun fisik dan reaksi emosional seperti mudah marah (Ekawati, Rahmawati and Wijaningsih, 2016).

\section{Hubungan Usia dengan Kelelahan Kerja}

Berdasarkan hasil uji chi square diperoleh nilai $p$-value $=1,000$ yang diartikan usia tidak memiliki hubungan dengan kelelahan kerja. Hasil uji statistik tersebut sejalan dengan penelitian Ferusgel (2017) yang mendapat p-value 0,625, karena rata-rata usia pekerja Molding Plant di PT. Pacific Medan Industri merupakan usia produktif (20-29 tahun). Penelitian ini tidak sejalan dengan penelitian Amalia dan Widajati (2019) yang menghasilkan uji statistik dengan nilai $<0,05$ sehingga diketahui ada hubungan antara usia dengan kelelahan kerja.

Hasil analisis data menurut tabel 5 tidak sependapat dengan teori yang dikemukakan oleh Suma'mur (1996) dalam Wahyuni dan Indriyani (2019) yang berpendapat bahwa usia seseorang berdampak pada kondisi tubuhnya, makin bertambah usia maka semakin meningkat kelelahan yang dirasakan karena dipengaruhi oleh ketahanan tubuh dan kapasitas kerja (Wahyuni and Indriyani, 2019). Hasil tersebut memberi gambaran bahwa tidak hanya pekerja yang berusia tua saja yang mengalami kelelahan kerja namun pekerja usia muda juga dapat mengalami kelelahan kategori tinggi. Penyebabnya karena pekerjaan yang dilakukan terlalu monoton sehingga menimbulkan rasa jenuh, dan dapat juga dipengaruhi oleh lingkungan kerja yang tidak mendukung seperti cuaca yang panas. Hal tersebut dapat juga disebabkan karena beban kerja yang diberikan terlalu berlebih terlihat dari tabel 4, seluruh pekerja memiliki beban kerja tinggi dan sangat tinggi. 


\section{Hubungan Status Gizi dengan Kelelahan Kerja}

Analisis uji chi-square memperoleh nilai $p$-value $=0,034$ yang artinya terdapat hubungan antara status gizi dengan kelelahan kerja, dan nilai OR sebesar 5,19 yang artinya pekerja berstatus gizi tidak normal berisiko 5,19 kali lebih besar mengalami kelelahan kerja kategori tinggi dibanding pekerja berstatus gizi normal. Penelitian ini tidak sejalan dengan penelitian Azwar, et al. (2018) serta penelitian Suryaningtyas (2017) yang berkesimpulan tidak ada hubungan antara faktor status gizi dengan kejadian kelelahan kerja. Penelitian ini sejalan dengan penelitian Paulina dan Salbiah (2016) yang memperoleh nilai $p$-value $=0,016$ dan nilai $\mathrm{r}=-0,431$ yang artinya semakin rendah atau buruk status gizi seseorang maka semakin tinggi tingkat kelelahan kerja nya.

Status gizi adalah salah satu penyebab terjadinya kelelahan kerja. Pekerja dengan status gizi nomal memiliki ketahanan tubuh dan kapasitas kerja yang lebih baik daripada pekerja dengan status gizi yang tidak normal. Status gizi berpengaruh positif terhadap kapasitas kerja, dimana jika asupan kalori pekerja tidak sesuai dengan keperluan yang dibutuhkan maka pekerja akan cepat merasa kelelahan sehingga pergerakkan tubuh menjadi lambat (Asriyani, Karimuna and Jufri, 2017). Status gizi sangat berkaitan dengan produktivitas kerja. Tubuh membutuhkan energi untuk bekerja, apabila intake energi kurang secara kualitas maupun kuantitas maka produktivitas kerja dapat terganggu. Perlu adanya keseimbangan antara intake dan output energi dalam tubuh, selain itu perlu juga badan yang sehat agar nutrisi dalam tubuh dapat diproses oleh organ tubuh dengan baik (Paulina and Salbiah, 2016).

\section{Hubungan Kualitas Tidur dengan Kelelahan Kerja}

Nilai $p$-value 0,028 dan nilai OR 5,49, nilai tersebut menunjukkan adanya hubungan antara kualitas tidur dan kelelahan kerja, selain itu pekerja dengan kualitas tidur yang buruk 5,49 kali lebih beresiko mengalami kelelahan daripada pekerja dengan kualitas tidur baik. Berdasarkan penelitian terdahulu, penelitian ini sejalan dengan penelitian yang dilakukan Azwar, et al. (2018) dengan nilai $p$-value $=0,002$, kualitas tidur dapat berpengaruh terhadap kelelahan karena tidur merupakan bentuk recovery tubuh, jika pemulihan tubuh baik maka individu lebih siap dan segar ketika melakukan pekerjaan.

Berdasarkan hasil analisis, rata-rata pekerja memperoleh total score kuesioner PSQI sebesar 5,98 yang artinya kebanyakan pekerja memang memiliki kualitas tidur yang buruk. Beberapa masalah tidur yang sering mengganggu tidur pekerja antara lain tidak dapat tidur selama 30 menit setelah berbaring, terbangun saat tengah malam karena ingin ke kamar kecil, serta kesulitan untuk tetap segar atau tidak merasa ngantuk saat bekerja. Pekerja di PT. Indonesia Power UPJP Priok rata-rata tidur selama 6 jam per 24 jam sehari, padahal individu yang berusia 18-40 tahun dianjurkan untuk tidur selama 7-8 jam (Azwar et al., 2018).

Kebiasaan tidur yang tidak buruk dapat mengganggu konsentrasi pekerja sehingga berpengaruh pada produktivitas dan kapasitas kerjanya (Nuraini, Winarko and Warno, 2018). Pekerja dengan kualitas tidur yang buruk dapat mengalami penurunan kemampuan kognitif, sering mengantuk, serta masalah kehadiran (keterlambatan, dan absensi). Masalah kesehatan yang dapat timbul akibat kebiasaan tidur yang buruk antara lain gangguan metabolisme dan kardiovaskuler, meningkatnya tekanan darah, berkurangnya system kekebalan tubuh, serta meningkatnya kerentanan tubuh terhadap penyakit (Azwar et al., 2018).

\section{SIMPULAN}

Terdapat hubungan antara status gizi dan kualitas tidur dengan kelelahan kerja di PT. Indonesia Power UPJP Priok.

Tidak ada hubungan antara usia dengan kelelahan kerja, serta tidak ada variabel faktor pekerjaan yang berhubungan dengan kelelahan kerja pada pekerja di PT. Indonesia Power UPJP Priok baik variabel masa kerja maupun variabel beban kerja.

\section{DAFTAR PUSTAKA}

Amalia, I. dan Widajati, N. (2019). Analisa Kelelahan Kerja Secara Obyektif berdasarkan Reaction Timer pada Tenaga Kerja Unit Pengerolan Besi PT.X. Journal

of Health Science and Prevention, (1), pp.1-9.

Asriyani, N., Karimuna, S. R. and Jufri, N. N. (2017). Faktor yang Berhubungan dengan 
Terjadinya Kelelahan Kerja pada Pekerja PT. Kalla Kakao Industri Tahun 2017. Jurnal Ilmiah Mahasiswa Kesehatan Masyarakat. 2(6): 1-10.

Azwar, A., Susilowati, I. H., Dinar, A., Indriyani, K., \& Wirawan, M. (2018). Impact of Work-related and Non-work-related Factors on Fatigue in Production/Shift Workers. KnE Life Sciences, 213-224.

Barlian, E. (2016), Metodologi Penelitian Kualitatif dan Kuantitatif. 1 (Satu). Padang: Sukabina Press. https://osf.io/preprints/inarxiv/aucjd/.

Binwasnaker, D. (2012). Kelelahan Akibat Pekerjaan. Jakarta: Erlangga.

Ekawati, H., Rahmawati, A. Y., \& Wijaningsih, W. (2016). Faktor Determinan Kelelahan Kerja Pada Tenaga Penjamah Makanan di Instalasi Gizi RS Dr R Soetijono Blora. JURNAL RISET GIZI, 4(2), 31-38.

Ferusgel, A. (2017). Faktor yang mempengaruhi kelelahan fisik kerja pada pekerja molding plant di PT. Pacific Medan Industri Tahun 2016. Jurnal kesehatan masyarakat dan lingkungan hidup, 2(1), 32-38.

ILO. (2013). Keselamatan dan Kesehatan Kerja. Modul $5 . \quad$ Jakarta. https://www.ilo.org/wcmsp5/groups/public /---asia/---ro-bangkok/---ilo-

jakarta/documents/publication/wcms_2376 50.pdf.

ILO. (2016). Workplace Stress: A Collective Challenge. Geneva: International Labour Organization Office.

Juliana, M., Camelia, A. dan Rahmiwati, A. (2018). Analisis Faktor Risiko Kelelahan Kerja Pada Karyawan Bagian Produksi PT. Arwana Anugrah Keramik, Tbk. Jurnal Ilmu Kesehatan Masyarakat. 9(1): 53-63.

Maharja, R.( 2015). Analisis Tingkat Kelelahan Kerja Berdasarkan Beban Kerja Fisik Perawat di Instalasi Rawat Inap RSU Haji Surabaya. The Indonesian Journal of Occupational Safety and Health. 4(1): 93102.

Mustofani and Dwiyanti, E. (2019). Relationship between Work Climate and Physical Workload with Work-Related Fatigue. The Indonesian Journal of Occupational Safety and Health. 8(2): 150-157.
Ningsih, S. N. P. dan Nilamsari, N. (2018). Faktor yang Berhubungan Dengan Kelelahan Pada Pekerja Dipo Lokomotif PT. Kereta Api Indonesia (Persero). Journal of Industrial Hygiene and Occupational Health. 3(1): 69-82.

NSC. (2017). Fatigue in The Workplace: Causes \& Consequences of Employee Fatigue. https://safety.nsc.org/fatigue-report.

Nuraini, N., Winarko and Warno, S. B. E. (2018). Faktor yang Berpengaruh terhadap Kelelahan (Studi Pada Pekerja Proyek Kapal Perang di PT. X Tahun 2018). Gema Kesehatan Lingkungan. 16(1): 266-273.

Paulina and Salbiah. (2016). Faktor-faktor yang Berhubungan dengan Kelelahan pada Pekerja di PT. Kalimantan Steel. Jurnal Vokasi Kesehatan. II(2): 165-172. https://ejournal.poltekkespontianak.ac.id/index.php/JVK/article/vie wFile/73/65.

Puspitasari, W., Wiediartini, W., \& Rosydah, B. M. (2018). Pengaruh Faktor Pekerja Dan Pekerjaan Terhadap Kelelahan Kerja Pada Area Cetak Pabrik Pengecoran. In Seminar K3 (Vol. 2, No. 1, pp. 549-552).

Suma'mur, P. K. (2014). Higiene Perusahaan dan Kesehatan Kerja (Hiperkes). Jakarta: PT. Sagung Seto.

Suryaningtyas, Y. (2017). Iklim Kerja Dan Status Gizi Dengan Kelelahan Kerja Pada Pekerja Di Ballast Tank Bagian Reparasi Kapal Pt. X Surabaya. Jurnal Manajemen Kesehatan Yayasan RS. Dr. Soetomo, 3(1), 17-32.

Tarwaka. (2010). Ergonomi Industri: Dasardasar Pengetahuan Ergonomi dan Aplikasi di Tempat Kerja. Surakarta: Harapan Press.

Verawati, L. (2016). Hubungan Tingkat Kelelahan Subjektif dengan Produktivitas pada Tenaga Kerja Bagian Pengemasan di $\mathrm{CV}$ Sumber Barokah. The Indonesian Journal of Occupational Safety and Health. 5(1): 51-60.

Wahyuni, D. and Indriyani. (2019). Faktor-faktor yang Berhubungan dengan Kelalahan Kerja pada Pekerja Bagian Produksi di PT. ANTAM Tbk. UBPP Logam Mulia. Jurnal Ilmu Kesehatan. 11(1): 73-79. 